FACTORS AFFECTING AUDIT DELAY WITH KAP REPUTATION AS MODERATING VARIABLE (STUDY ON LQ 45 COMPANIES LISTED ON THE INDONESIA STOCK EXCHANGE IN 2015 - 2019)

\title{
FAKTOR-FAKTOR YANG MEMPENGARUHI AUDIT DELAY DENGAN REPUTASI KAP SEBAGAI VARIABEL PEMODERASI (STUDI PADA PERUSAHAAN LQ 45 YANG TERDAFTAR DI BURSA EFEK INDONESIA PADA TAHUN 2015 - 2019)
}

\author{
Oleh: \\ Fuad Rahardi' ${ }^{1}$, Afrizal ${ }^{2)}$, Enggar Diah PA $^{3)}$ \\ ${ }^{1)}$ Alumni Magister Ilmu Akuntansi Pascasarjana Universitas Jambi \\ ${ }^{2 \& 3)}$ Dosen Jurusan Akuntansi Fakultas Ekonomi dan Bisnis Universitas Jambi \\ Email: ${ }^{1)}$ fuadrahardi@gmail.com, ${ }^{2)}$ afrizaldoktor@unja.ac.id, ${ }^{3)}$ enggar_diah@unja.ac.id
}

\begin{abstract}
ABSTRCT
This study aimed to analyze the effect of company size, audit opinion, solvency, profitability and audit committee on audit delay with the reputation of Public Accountant as a moderating variable. The population of this study were companies listed in the LQ-45 index in the Indonesia Stock Exchange on 2015 - 2019. The sampling technique used was purposive sampling method, that the samples were selected based on the suitability of the sample characteristics with the specified samples selection criteria. Data analysis in this study used panel data analysis and absolute difference test. The results of this study indicated that: solvency and audit committee had a positive and significant effect on audit delay, while profitability had a negative and significant effect on audit delay. Meanwhile, company size and audit opinion had no effect on audit delay. The results of this study also showed that the reputation of KAP was able to moderate the relationship between firm size and solvency with audit delay and was unable to moderate the relationship between audit opinion, profitability and audit committee with audit delay.
\end{abstract}

Keywords: Audit delay, company size, audit opinion, solvency, profitability, audit committee, and KAP reputation.

\begin{abstract}
ABSTRAK
Penelitian ini bertujuan untuk menganalisis pengaruh ukuran perusahaan, opini audit, solvabilitas, profitabilitas dan komite audit terhadap audit delay dengan reputasi KAP sebagai variabel pemoderasi. Populasi penelitian ini adalah perusahaan yang terdaftar dalam indeks LQ-45 tahun 2015 - 2019 di Bursa Efek Indonesia. Teknik penarikan sampel penelitian adalah dengan menggunakan metode purposive sampling yaitu sampel dipilih atas dasar kesesuaian karakteristik sampel dengan kriteria pemilihan sampel yang ditentukan. Analisis data dalam penelitian ini menggunakan analisis data panel dan uji selisih mutlak. Hasil penelitian ini menunjukkan bahwa: solvabilitas dan komite audit berpengaruh positif dan signifikan terhadap audit delay, sedangkan profitabilitas berpengaruh negatif dan signifikan terhadap audit delay. Sementara itu, ukuran perusahaan dan opini audit tidak berpengaruh terhadap audit delay. Hasil penelitian ini juga menunjukkan bahwa reputasi KAP mampu memoderasi hubungan ukuran perusahaan dan solvabilitas dengan audit delay dan tidak mampu memoderasi hubungan opini audit, profitabilitas dan komite audit dengan audit delay.

Kata kunci: Audit delay, ukuran perusahaan, opini audit, solvabilitas, profitabilitas, komite audit, dan reputasi KAP.
\end{abstract}




\section{PENDAHULUAN}

\subsection{Latar Belakang}

Laporan keuangan adalah hasil akhir dari proses akuntansi yang memberikan informasi tentang kondisi keuangan secara keseluruhan suatu entitas yang dibuat oleh pihak pengelola untuk mempertanggungjawabkan kinerja yang mereka lakukan selama periode tertentu kepada pemakai laporan keuangan yang berguna dalam pengambilan keputusan. Informasi keuangan tersebut juga berguna untuk mengevaluasi kinerja manajerial dan organisasi. Namun, terkadang laporan keuangan tidak menyediakan semua informasi yang dibutuhkan pemakai dalam mengambil keputusan sehingga diperlukan pihak ketiga yang independent atau auditor untuk melakukan pemeriksaan terhadap laporan keuangan perusahaan.

Sutabri (2012) mengungkapkan bahwa kualitas informasi tergantung dari 3 hal, yaitu (a) informasi harus akurat dimana informasi tersebut harus bebas dari kesalahan-kesalahan dan tidak menyesatkan; (b) tepat waktu (timeliness), informasi yang diterima tidak boleh terlambat, karena informasi merupakan suatu landasan dalam mengambil sebuah keputusan dan apabila terjadi keterlambatan dalam pengambilan keputusan maka akan berakibat fatal untuk organisasi; dan (c) relevan (relevance), maksudnya informasi tersebut mempunyai nilai manfaat bagi pemakainya. Relevansi informasi untuk setiap orang berbeda, misalnya informasi tentang penyebab kerusakan mesin produksi menjadi tidak relevan jika disampaikan kepada akuntan perusahaan.

$$
\text { OJK mengeluarkan peraturan No.44 }
$$

/POJK/.04/2016 mengenai Penyampaian Laporan Keuangan Berkala Emiten dan Perusahaan Publik. Peraturan ini menyatakan bahwa laporan keuangan tahunan wajib disertai laporan akuntan dalam rangka audit atas laporan keuangan, dan wajib disampaikan kepada OJK serta diumumkan kepada masyarakat paling lambat pada akhir bulan ketiga setelah tanggal laporan keuangan tahunan perusahaan. OJK mengharuskan perusahaan publik melaporkan laporan keuangan yang telah diaudit dalam 60 sampai 90 hari setelah penutupan periode pembukuan (Arens et al, 2011).

Peraturan tersebut tidak cukup membuat perusahaan tepat waktu dalam penyampaian laporan keuangan. Beberapa catatan mengungkapkan masih terdapat beberapa emiten yang terlambat dalam penyampaian laporan keuangan. Berdasarkan catatan Bursa Efek Indonesia hingga tanggal 31 Maret 2015, menyebutkan 52 perusahaan belum menyampaikan laporan keuangan tepat waktu terkait penyampaian laporan keuangan auditan yang berakhir per 31 Desember 2014. Keterangan mengenai perusahaan tersebut 13 perusahaan tercatat menyampaikan informasi mengenai keterlambatan penyampaian laporan keuangan sedangkan 39 perusahaan tidak menyampaikan informasi mengenai keterlambatannya. Sementara itu, pada perusahaan yang terdaftar dalam Indeks LQ-45 periode 2015 - 2019, masih ada emiten yang terlambat dalam penyelesaian auditnya. Laporan audit PT. Wijaya Karya tahun 2015 dan 2016 baru diselesaikan pada bulan oktober tahun berjalan. Pada tahun 2019, sebanyak 3 emiten juga terlambat dalam menyelesaikan auditnya yaitu PT. Surya Citra Media yang baru menerbitkan laporan tanggal 9 April, PT. Waskita Karya mempublikasikan laporan keuangan tanggal 21 April, dan PT. Telkom Indonesia menerbitkan laporan keuangannya tanggal $25 \mathrm{Mei}$.

Ukuran perusahaan merupakan salah satu faktor yang mempengaruhi audit delay. Ukuran perusahaan menunjukkan besarnya lingkup atau luas perusahaan dalam menjalankan operasinya. Ukuran perusahan dapat dilihat dari total aset atau kekayaan yang dimiliki oleh perusahaan. Perusahaan berskala besar memiliki citra yang baik di mata publik dan biasanya dimonitor dengan ketat oleh pihak yang berkepentingan. Perusahaan besar cenderung mendapat tekanan untuk segera melaporkan laporan keuangan sehingga tepat waktu dalam penyampaiannya. Hal ini membuat manajemen perusahaan bekerja secara lebih profesional sehingga proses penyusunan laporan dan auditnya lebih cepat (Ari Murti dan Widhiyani, 2016).

Opini audit juga merupakan faktor yang mempengaruhi audit delay. Opini audit adalah pernyataan standar dari kesimpulan auditor yang diperoleh berdasarkan kesimpulan dari proses audit, dalam laporan audit terdapat temuan auditor yang diungkapkan melalui bentuk opini audit atas kewajaran laporan keuangan (Arens, et.al., 2016). Dalam laporan audit terdapat temuan auditor yang dinyatakan melalui opini audit atas kewajaran laporan keuangan. Menurut Carslaw dan Kaplan dalam Yuliusman et.al. (2020), perusahaan yang tidak menerima opini audit standar wajar tanpa pengecualian diperkirakan akan mengalami penundaan audit yang lebih lama karena perusahaan yang menerima opini tersebut dipandang sebagai berita buruk dan akan memperlambat proses audit.

Faktor lain yang mempengaruhi audit delay yaitu faktor solvabilitas perusahaan. Solvabilitas atau debt ratio adalah rasio yang digunakan untuk mengukur sejauhmana aset perusahaan dibiayai oleh hutang (Kasmir, 2015). Artinya besarnya jumlah hutang yang digunakan oleh perusahaan untuk membiayai kegiatan usahanya jika dibandingkan dengan menggunakan modal sendiri. Solvabilitas yang tinggi merupakan kabar buruk bagi investor, sehingga manajemen perusahaan berusaha untuk memperpanjang auditor untuk melakukan audit, sehingga penyampaian laporan keuangan menjadi lebih lama. Semakin tinggi tingkat solvabilitas perusahaan akan membuat audit delay semakin lama. Rasio solvabilitas yang tinggi akan cenderung memiliki rentang waktu penyajian laporan keuangan yang lebih lama, sehingga informasi yang disajikan mengandung unsur "good news" atau "bad news" dari laporan keuangan (Laksono dan Mu'id, 2014).

Profitabilitas merupakan faktor lain yang juga mempengaruhi audit delay. Profitabilitas merupakan 
Faktor-Faktor yang Mempengaruhi Audit Delay dengan Reputasi KAP Sebagai Variabel Pemoderasi (Studi Pada Perusahaan LQ 45 yang Terdaftar di Bursa Efek Indonesia Pada Tahun 2015 - 2019) (Fuad Rahardi, Afrizal, dan Enggar Diah PA)

indikator keberhasilan kinerja perusahaan untuk menghasilkan laba. Profitabilitas dapat dilihat dari tingkat rasio Return On Asset (ROA) yang menunjukkan kemampuan perusahaan dalam menggunakan aset dalam menghasilkan laba bagi perusahaan tersebut. Tingkat keuntungan digunakan sebagai salah satu cara untuk menilai keberhasilan efektivitas perusahaan (Kartika, 2011). Perusahaan akan cenderung ingin mempublikasikan laporan keuangan yang telah diaudit secara lebih cepat apabila memiliki profitabilitas yang baik yang menunjukkan prestasi perusahaan. Hal ini merupakan berita baik yang dapat memberikan sinyal yang positif kepada para pemangku kepentingan dalam mengambil keputusan dan demikian juga sebaliknya perusahaan yang memiliki profitabilitas buruk akan cenderung menunda publikasi. Hal ini dikarenakan perusahaan ingin menunda bad news karena hal itu akan memberi sinyal yang negatif.

Komite audit mempunyai peran yang sangat penting dan strategis dalam hal memelihara kredibilitas proses penyusunan laporan keuangan seperti halnya menjaga terciptanya sistem pengawasan perusahaan yang memadai serta dilaksanakannya corporate governance (FCGI, 2000). Bapepam-LK saat ini OJK No.IX.I.7 (2008) menyatakan bahwa auditor internal merupakan unit yang bertanggung jawab untuk memberikan kepercayaan dan proses konsultasi secara independen dan obyektif guna meningkatkan nilai dan operasional perusahaan dengan pendekatan yang sistematis. Dengan demikian, auditor internal perusahaan dapat menciptakan operasional perusahaan yang efektif. Suharni et.al. (2013) menyatakan bahwa jumlah anggota auditor internal berpengaruh terhadap ketepatan waktu. Ketepatan waktu laporan keuangan perusahaan berkaitan dengan waktu penyelesaian laporan audit auditor independen atas laporan keuangan. Dengan demikian, jumlah anggota auditor internal juga mempengaruhi audit delay.

Penelitian tentang faktor-faktor yang mempengaruhi audit delay telah dilakukan oleh Yuliusman et.al. (2020) dengan judul Determinant Factors Audit Delay: Evidence from Indonesia. Penelitian tersebut meneliti pengaruh profitabilitas, solvabilitas, ukuran perusahaan, opini audit, dan ukuran KAP sebagai faktor yang mempengaruhi audit delay. Hasil penelitian menunjukkan bahwa secara simultan atau parsial profitabilitas, solvabilitas, ukuran perusahaan, opini audit, dan ukuran Kantor Akuntan Publik mempengaruhi audit delay.

Penelitian lain dilakukan oleh Fanny et.al. (2019) dengan judul Analysis of Factors Affecting the Audit Delay in Manufacturing Companies Listedi Indonesia Stock Exchange in 2013-2015. Penelitian ini dilakukan untuk meneliti pengaruh profitabilitas, solvabilitas, dan ukuran perusahaan terhadap audit delay. Hasil penelitian menunjukkan bahwa profitabilitas dan ukuran perusahaan berpengaruh negatif terhadap audit delay. Sedangkan solvabilitas tidak berpengaruh terhadap audit delay.
Penelitian lain yang meneliti mengenai faktorfaktor yang mempengaruhi audit delay juga dilakukan oleh Syachruddin dan Nurlis (2018) dengan judul Influence of Company Size, Audit Opinion, Profitability, Solvency, And Size Of Public Accountant Offices To Delay Audit On Property Sector Manufacturing Companies Listed In Indonesia Stock Exchange. Penelitian ini menguji pengaruh ukuran perusahaan, opini audit, solvabilitas, dan ukuran KAP terhadap audit delay. Hasil penelitian menemukan bahwa hanya profitabilitas yang berpengaruh negatif dan signifikan terhadap audit delay, sedangkan ukuran perusahaan, opini audit, solvabilitas, dan ukuran KAP tidak berpengaruh terhadap audit delay.

Penelitian Juwita et.al. (2020) menempatkan variabel ukuran KAP sebagai pemoderasi pengaruh komite audit dan internal audit terhadap keterlambatan laporan audit. Hasil penelitian tersebut menunjukkan bahwa komite audit berpengaruh terhadap keterlambatan laporan audit sedangkan audit internal tidak berpengaruh. Ukuran kantor akuntan publik berhasil memoderasi hubungan antara komite audit dan audit report lag, tetapi gagal memoderasi hubungan antara audit internal dan audit report lag. Sementara itu, penelitian Ari Murti dan Widhiyani (2016) menempatkan variabel reputasi KAP menjadi pemoderasi pengaruh ukuran perusahaan dan profitabilitas terhadap audit delay. Hasil penelitian tersebut menunjukkan bahwa ukuran perusahaan dan profitabilitas berpengaruh negatif pada audit delay. Reputasi KAP terbukti memoderasi pengaruh ukuran perusahaan dan profitabilitas pada audit delay.

Penelitian ini merupakan pengembangan dari penelitian yang dilakukan oleh Yuliusman et.al. (2020), Fanny et.al. (2019), Syachruddin dan Nurlis (2018), dan Putra et.al. (2017) yang meneliti faktor-faktor yang mempengaruhi audit delay. Peneliti berpendapat bahwa perbedaan publikasi laporan keuangan auditan perusahaan atau Audit Delay dapat disebabkan oleh beberapa faktor yang akibatnya dapat berpengaruh terhadap rekasi investor. Berdasarkan penelitianpenelitian tersebut, maka faktor-faktor yang mempengaruhi audit delay antara lain ukuran perusahaan, opini audit, solvabilitas, profitabilitas, dan komite audit. Dari beberapa penelitian sebelumnya masih menunjukkan hasil yang beragam sehingga belum terlihat adanya konsistensi hasil penelitian.

Perbedaan penelitian ini dengan penelitian sebelumnya yaitu dengan menempatkan variabel reputasi KAP sebagai pemoderasi hubungan antara ukuran perusahaan, opini audit, solvabilitas, profitabilitas, dan komite audit dengan audit delay. Kantor Akuntan Publik akan melaksanakan prosedur audit sesuai dengan standar yang berlaku untuk dapat menghasilkan laporan keuangan yang berkualitas untuk dapat memberikan informasi yang dapat digunakan sebagai dasar pengambilan keputusan. Murti dan Widhiyani (2016) menyatakan bahwa reputasi KAP berpengaruh pada kualitas audit. Kualitas audit yang baik tentunya tidak mengalami audit delay yang panjang. Perusahaan yang menggunakan kantor 
akuntan publik besar seperti The Big Four cenderung lebih dipilih oleh investor karena investor menganggap perusahaan dengan KAP besar akan dapat menghasilkan kualitas audit yang baik daripada KAP kecil (Handayani, 2013).

Perbedaan lainnya yaitu alat analisis yang digunakan dimana peneliti menggunakan analisis regresi data panel dan uji selisih mutlak untuk menguji pengaruh moderasi reputasi KAP terhadap hubungan ukuran perusahaan, opini audit, solvabilitas, profitabilitas, dan komite audit. Analisis data panel dilakukan sesuai dengan karakteristik data yang merupakan gabungan antara data cross section dan time series. Alasan penelitian menggunakan data panel, karena terdapat beberapa keunggulan penggunaan data panel dibandingkan dengan data time series dan cross section. Pertama, dapat memberikan sejumlah data yang lebih besar, menaikkan derajat kebebasan, mengurangi kolinearitas di antara variabel penjelas, sehingga diperoleh estimasi ekonometrik yang efisien. Kedua, memberikan informasi yang penting bagi peneliti yang tidak dapat diberikan jika menggunakan data time series dan cross section (Gujarati, 2012).

\subsection{Rumusan Masalah}

Berdasarkan uraian di atas, maka pokok permasalahan dalam penelitian ini akan dirumuskan dalam bentuk pertanyaan yaitu sebagai berikut:

1. Bagaimana pengaruh ukuran perusahaan terhadap audit delay pada perusahaan LQ 45 yang terdaftar di Bursa Efek Indonesia pada tahun 2015 - 2019?

2. Bagaimana pengaruh opini auditor terhadap audit delay pada perusahaan LQ 45 yang terdaftar di Bursa Efek Indonesia pada tahun 2015 - 2019?

3. Bagaimana pengaruh solvabilitas terhadap audit delay pada perusahaan LQ 45 yang terdaftar di Bursa Efek Indonesia pada tahun 2015 - 2019?

4. Bagaimana pengaruh profitabilitas terhadap audit delay pada perusahaan LQ 45 yang terdaftar di Bursa Efek Indonesia pada tahun 2015 - 2019?

5. Bagaimana pengaruh komite audit terhadap audit delay pada perusahaan LQ 45 yang terdaftar di Bursa Efek Indonesia pada tahun 2015 - 2019?

6. Bagaimana pengaruh reputasi KAP memoderasi hubungan ukuran perusahaan dengan audit delay pada perusahaan LQ 45 yang terdaftar di Bursa Efek Indonesia pada tahun 2015 - 2019?

7. Bagaimana pengaruh reputasi KAP memoderasi hubungan opini auditor dengan audit delay pada perusahaan LQ 45 yang terdaftar di Bursa Efek Indonesia pada tahun 2015 - 2019?

8. Bagaimana pengaruh reputasi KAP memoderasi hubungan solvabilitas dengan audit delay pada perusahaan LQ 45 yang terdaftar di Bursa Efek Indonesia pada tahun 2015 - 2019?

9. Bagaimana pengaruh reputasi KAP memoderasi hubungan profitabilitas dengan audit delay pada perusahaan LQ 45 yang terdaftar di Bursa Efek Indonesia pada tahun 2015 - 2019?

10. Bagaimana pengaruh reputasi KAP memoderasi hubungan komite audit dengan audit delay pada perusahaan LQ 45 yang terdaftar di Bursa Efek Indonesia pada tahun 2015 - 2019?

\subsection{Rumusan Masalah}

Berdasarkan latar belakang tersebut, maka tujuan penelitian ini adalah sebagai berikut:

1. Untuk menganalisis pengaruh ukuran perusahaan terhadap audit delay pada perusahaan LQ 45 yang terdaftar di Bursa Efek Indonesia pada tahun 2015 $-2019$.

2. Untuk menganalisis pengaruh opini auditor terhadap audit delay pada perusahaan LQ 45 yang terdaftar di Bursa Efek Indonesia pada tahun 2015 $-2019$.

3. Untuk menganalisis pengaruh solvabilitas terhadap audit delay pada perusahaan LQ 45 yang terdaftar di Bursa Efek Indonesia pada tahun 2015 - 2019.

4. Untuk menganalisis pengaruh profitabilitas terhadap audit delay pada perusahaan LQ 45 yang terdaftar di Bursa Efek Indonesia pada tahun 2015 $-2019$.

5. Untuk menganalisis pengaruh komite audit terhadap audit delay pada perusahaan LQ 45 yang terdaftar di Bursa Efek Indonesia pada tahun 2015 - 2019.

6. Untuk menganalisis pengaruh reputasi KAP memoderasi hubungan ukuran perusahaan dengan audit delay pada perusahaan LQ 45 yang terdaftar di Bursa Efek Indonesia pada tahun 2015 - 2019.

7. Untuk menganalisis pengaruh reputasi KAP memoderasi hubungan opini auditor dengan audit delay pada perusahaan LQ 45 yang terdaftar di Bursa Efek Indonesia pada tahun 2015 - 2019.

8. Untuk menganalisis pengaruh reputasi KAP memoderasi hubungan solvabilitas dengan audit delay pada perusahaan LQ 45 yang terdaftar di Bursa Efek Indonesia pada tahun 2015 - 2019.

9. Untuk menganalisis pengaruh reputasi KAP memoderasi hubungan profitabilitas dengan audit delay pada perusahaan LQ 45 yang terdaftar di Bursa Efek Indonesia pada tahun 2015 - 2019.

10. Untuk menganalisis pengaruh reputasi KAP memoderasi hubungan komite audit dengan audit delay pada perusahaan LQ 45 yang terdaftar di Bursa Efek Indonesia pada tahun 2015 - 2019.

\subsection{Manfaat Penelitian}

\subsubsection{Manfaat Keilmuan Teoritis}

Manfaat teoritis dari penelitian ini adalah menjadi tambahan referensi atau rujukan bagi mahasiswa/peneliti selanjutnya, khususnya mengenai faktor-faktor yang mempengaruhi audit delay dengan reputasi KAP sebagai variabel pemoderasi.

\subsubsection{Manfaat Praktik}

1. Bagi Penulis

Untuk menempuh ujian tingkat magister pada Program Pascasarjana Magister Ilmu Akuntansi Fakultas Ekonomi dan Bisnis Universitas Jambi.

2. Bagi Instansi Pendidikan 
Memberikan tambahan sumber referensi bagi perpustakaan Magister Ilmu Akuntansi mengenai faktor-faktor yang mempengaruhi audit delay dengan reputasi KAP sebagai variabel pemoderasi.

\section{KAJIAN PUSTAKA, KERANGKA PEMIKIRAN}

\subsection{Audit}

Audit adalah proses akumulasi dan evaluasi bukti mengenai informasi untuk menentukan dan melaporkan tingkat kesesuaian antara informasi yang diungkapkan perusahaan dengan standar akuntansi yang berlaku umum (Arens et.al., 2011). Auditor eksternal adalah orang yang menjalankan fungsi audit ini sehingga jasa yang ditawarkan oleh auditor eksternal adalah jasa assurance yang berfungsi untuk meningkatkan kualitas informasi dari para pembuat keputusan. Dalam melaksanakan jasa tersebut, auditor eksternal tidak hanya memeriksa apakah penyajian laporan keuangan sudah sesuai ketentuan tetapi juga melihat kondisi pengendalian internal dalam perusahaan untuk kepentingan proses audit selanjutnya.

Standar Profesional Akuntansi Publik (2011) menjelaskan mengenai audit sebagai proses pengumpulan dan pengevaluasian bahan bukti tentang informasi yang dapat diukur mengenai suatu entitasi ekonomi yang dilakukan seseorang yang komperen dan indepeden untuk dapat menentukan dan melaporkan kesesuaian informasi dimaksud dengan kriteria-kriteria yang telah ditetapkan. Auditing seharusnya dilakukan oleh seorang independen dan komponen.

\subsection{Laporan Audit}

Mulyadi (2013) mengungkapkan bahwa laporan audit merupakan media yang dipakai oleh auditor untuk melakukan komunikasi dengan masyarakat dan lingkungannya. Di dalam laporan tersebut auditor menyatakan pendapatnya mengenai kewajaran laporan keuangan perusahaan yang telah diaudit. Pendapat auditor atau opini disampaikan dalam bentuk tertulis berupa laporan audit baku. Lebih lanjut menurut Mulyadi (2013) disebutkan bahwa laporan audit biasanya terdiri dari tiga paragraf yaitu: paragraf pengantar (introductory paragraph), paragraf lingkup (scope paragraph), dan paragraf pendapat (opinion paragraph).

\subsection{Laporan Keuangan}

Laporan keuangan perusahaan merupakan sumber informasi yang penting mengenai kondisi keuangan perusahaan bagi pihak-pihak yang berkepentingan di luar struktur organisasi perusahaan. Setiap perusahaan yang go public mempunyai kewajiban untuk mempublikasikan laporan keuangannya setiap tahun buku dan disusun berdasarkan standar akuntansi keuangan yang ditetapkan serta telah diaudit oleh Kantor Akuntan Publik (KAP) yang telah terdaftar pada Otoritas Jasa keuangan (OJK). Laporan keuangan terdiri dari:

1. Neraca (Balance Sheet)
Neraca merupakan unsur dari sebuah laporan yang menyajikan tentang posisi keuangan perusahaan pada titik waktu tertentu (Bringham dan Houston, 2018). Di sisi kiri persamaan ini terkait dengan sumber daya yang dikendalikan oleh perusahaan, atau aktiva sumber daya yang merupakan investasi yang diharapkan untuk menghasilkan laba di masa depan melalui aktiva operasi sisi kanan persamaan ini yang mengidentifikasi sumber pendanaan. Kewajiban (liability) merupakan pendanaan dari kreditor dan mewakili kewajiban perusahaan, atau klaim kreditor atas aktiva. Ekuitas merupakan modal pemegang saham (shareholders equity) yaitu total dari dana yang diinvestasikan oleh pemilik dan laba akuntansi yang diperoleh perusahaan setiap tahunnya yang tidak dibagikan kepada pemilik (laba ditahan) sejak berdirinya perusahaan.

2. Laporan Laba Rugi (Income Statement)

Laporan laba rugi merupakan unsur laporan keuangan yang mengikhtisarkan pendapatan dan pengeluaran perusahaan selama satu periode akuntansi, yang biasanya setiap satu kuartal atau satu tahun (Bringham dan Houston, 2018). Laporan laba rugi menunjukkan ukuran kinerja keuangan perusahaan karena mencerminkan aktivitas operasi perusahaan. Laporan laba rugi pada umumnya menyajikan rincian pendapatan, beban, untung, dan rugi perusahaan untuk suatu periode waktu.

3. Laporan Arus Kas

Laporan arus kas merupakan unsur laporan keuangan laporan yang melaporkan dampak dari aktivitas-aktivitas operasi, investasi, dan pendanaan oleh perusahaan pada arus kas selama satu periode akuntansi (Bringham dan Houston, 2018). Tujuan dari laporan arus kas yaitu untuk memberikan informasi mengenai penerimaan dan pembayaran kas perusahaan selama periode tertentu.

\subsection{Audit Delay}

Audit delay adalah jeda waktu audit, yaitu waktu yang dibutuhkan oleh auditor untuk menghasilkan laporan audit atas laporan keuangan kinerja suatu perusahaan (Fanny et.al., 2019). Gap waktu audit ini dihitung dari selisih antara tanggal laporan keuangan tahunan perusahaan sampai dengan tanggal laporan audit yang diterbitkan oleh KAP. Hal ini sesuai dengan definisi Halim (2007) dalam Fanny et.al. (2019) yang menyebutkan bahwa audit delay diartikan sebagai lamanya waktu yang diukur dari tanggal penyelesaian audit tahun buku sampai dengan tanggal diterbitkannya laporan audit.

\subsection{Ukuran Perusahaan}

Menurut Brigham dan Houston (2018) ukuran perusahaan merupakan ukuran besar kecilnya sebuah perusahaan yang ditunjukan atau dinilai oleh total asset, total penjualan, jumlah laba, beban pajak dan lain-lain. Sementara itu, Hartono (2008) mengungkapkan bahwa ukuran perusahaan (firm size) adalah besar kecilnya perusahaan yang dapat diukur dengan total aktiva/besar 
harta perusahaan dengan menggunakan perhitungan nilai logaritma total aktiva. Semakin besar asset yang dimiliki perusahaan maka semakin besar ukuran perusahaan. Jika nilai total asset langsung dipakai begitu saja maka nilai variabel akan sangat besar, miliar bahkan triliun. Karena total asset perusahaan bernilai besar maka hal ini dapat disederhanakan dengan mentransformasikannya kedalam logaritma natural, tanpa mengubah proporsi dari nilai asal yang sebenarnya.

\subsection{Opini Auditor}

Menurut Mulyadi (2013), terdapat lima jenis opini atau pendapat auditor atas laporan audit yang diterbitkan yaitu:

1. Pendapat wajar tanpa pengecualian (Unqualified Opinion)

Pendapat ini diberikan oleh auditor jika tidak terjadi pembatasan dalam lingkup audit dan terdapat pengecualian yang signifikan mengenai kewajaran dan penerapan prinsip akuntansi berterima umum dalam penyusunan laporan keuangan dan konsistensi penerapan prinsip akuntansi berterima umum, serta pengungkapan memadai dalam laporan keuangan.

2. Pendapat wajar tanpa pengecualian dengan bahasa penjelasan (Unqualified Opinion report with Explanatory Language)

Pendapat wajar tanpa pengecualian yang menggunakan bahasa penjelasan diberikan manakala audit telah dilaksanakan atau telah sesuai dengan prinsip akuntansi yang diterima umum, namun masih terdapat keadaan tertentu yang mengharuskan auditor menambahkan suatu paragraf penjelasan dalam laporan audit. Penjelasan tambahan tersebut tidak mempengaruhi pendapat wajar tanpa pengecualian atas laporan keuangan.

3. Pendapat wajar dengan pengecualian (Qualified Opinion)

Auditor memberikan pendapat wajar dengan pengecualian dalam laporan audit apabila lingkup audit dibatasi klien. Karena batasan tersebut membuat auditor tidak bisa melaksanakan prosedur audit penting atau tidak dapat memperoleh informasi penting yang terjadi karena adanya kondisi-kondisi yang berada di luar kekuasaan klien maupun auditor. Laporan keuangan tidak disusun dengan prinsip akuntansi yang diterima umum.

4. Pendapat tidak wajar (adverse Opinion)

Opini audit tidak wajar diberikan jika laporan keuangan klien tidak disusun berdasarkan prinsip akuntansi yang diterima umum sehingga laporan keuangan tidak menyajikan secara wajar mengenai posisi keuangan perusahaan, hasil usaha, perubahan ekuitas, dan arus kas perusahaan klien.

5. Pernyataan tidak memberikan pendapat (Disclaimer of Opinion)

Auditor tidak menyatakan pendapat terjadi jika terdapat kondisi sebagai berikut: a. Pembatasan yang luar biasa sifatnya terhadap lingkungan audit.

b. Auditor tidak independen dalam hubungannya dengan kliennya.

\subsection{Solvabilitas}

Solvabilitas atau debt ratio adalah rasio yang digunakan untuk mengukur sejauhmana aset perusahaan dibiayai oleh hutang (Kasmir, 2015). Artinya besarnya jumlah hutang yang digunakan oleh perusahaan untuk membiayai kegiatan usahanya jika dibandingkan dengan menggunakan modal sendiri.Sementara itu, menurut Hanafi dan Halim (2016), solvabilitas merupakan kemampuan perusahaan untuk memenuhi semua kewajiban-kewajibannya baik kewajiban jangka pendek maupun jangka panjangnya. Lebih lanjut menurut Hanafi dan Halim (2016) mengungkapkan bahwa perusahaan perusahaan yang memiliki nilai total utang yang lebih besar dibandingkan total asetnya merupakan perusahaan yang tidak solvabel.

Berdasarkan definisi di atas, maka dalam penelitian ini yang menjadi tolak ukur Solvabilitas diukur dengan rasio total debt to total asset ratio (TDTA) yang membandingkan jumlah utang (baik jangka pendek ataupun jangka panjang) dengan jumlah aktiva (total aset) dengan. Perhitungan solvabilitas dengan rasio total debt to total aset (TDTA) sendiri di hitung dengan rumus:

TDTA $=\frac{\text { Total Utang }}{\text { Total Aktiva }} \times 100 \%$

\subsection{Profitabilitas}

Profitabilitas merupakan kemampuan perusahaan untuk memperoleh laba selama periode tertentu (Munawir, 2010). Definisi profitabilitas menurut Brigham dan Houston (2018) menyebutkan bahwa profitabilitas adalah hasil bersih dari serangkaian kebijakan dan keputusan yang dihitung melalui berbagai tolak ukur yang relevan. Salah satu tolak ukur untuk menentukan profitabilitas yaitu melalui analisis rasio keuangan yang merupakan salah satu analisa mengenai kondisi keuangan suatu perusahaan.

\subsection{Komite Audit}

Komite audit bertugas untuk memantau perencanaan dan pelaksanaan kemudian mengevaluasi hasil audit guna menilai kelayakan dan kemampuan pengendalian interen termasuk mengawasi proses penyusunan laporan keuangan. Komite audit dapat merupakan pihak yang melakukan pengawasan terkait dengan informasi keuangan dan laporan keuangan perusahaan. Peraturan BAPEPAM saat ini OJK No. IX.I.5 tahun 2012 menjelaskan bahwa komite audit bertanggung jawab untuk melakukan penelaahan atas informasi keuangan perusahaan dan pelaksanaan audit oleh auditor internal, dan pengaduan yang terkait dengan proses akuntansi perusahaan. Komite audit pada perusahaan dengan kompleksitas tinggi akan memiliki tugas yang lebih rumit dibandingkan dengan komite audit pada perusahaan dengan kompleksitas audit rendah. Hal ini dikarenakan komite audit pada perusahaan dengan kompleksitas audit yang tinggi akan 
Faktor-Faktor yang Mempengaruhi Audit Delay dengan Reputasi KAP Sebagai Variabel Pemoderasi (Studi Pada Perusahaan LQ 45 yang Terdaftar di Bursa Efek Indonesia Pada Tahun 2015 - 2019) (Fuad Rahardi, Afrizal, dan Enggar Diah PA)

melakukan informasi keuangan dan proses akuntansi yang lebih kompleks.

\subsection{Reputasi Kantor Akuntan Publik}

Peraturan Menteri Keuangan No:

25/PMK.01/2014 tentang Akuntan Beregister Negara menyebutkan bahwa Kantor Jasa Akuntansi adalah badan usaha yang telah mendapatkan izin dari Menteri untuk memberikan jasa akuntansi selain asurans. Reputasi Kantor Akuntan Publik (KAP) dilihat dari KAP yang berafiliasi dengan Big Four dan yang tidak berafiliasi dengan Big Four. Arens et al. (2011) menyatakan bahwa penggolongan ukuran besar kecilnya kantor akuntan publik, dikatakan besar jika kantor akuntan publik tersebut berafiliasi atau mempunyai cabang dan kliennya perusahaanperusahaan besar mempunyai tenaga profesional di atas 25 orang. KAP tergolong sebagai KAP dengan ukuran yang kecil jika tidak berafiliasi dengan perusahaan akuntan internasional yang tergolong dalam KAP Big Four. KAP Big 4 merupakan perusahaan akuntansi internasional yang bergerak dalam bidang audit, dan konsultasi untuk perusahaan perdagangan dan swasta yang terbesar.

\subsection{Kerangka Pemikiran}

2.11.1. Hubungan Ukuran Perusahaan dan Audit Delay

Yuliusman et.al. (2020) menemukan bahwa ukuran perusahaan mempengaruhi Audit Delay. Semakin besar nilai aktiva perusahaan membuat audit delay semakin pendek, sebaliknya jika ukuran perusahaan semakin kecil maka audit delay menjadi semakin lama. Hasil penelitian lain yang dilakukan oleh Fanny et.al. (2019) menemukan bahwa ukuran perusahaan berpengaruh signifkan terhadap Audit Delay yang berarti bahwa besar kecilnya ukuran perusahaan mempengaruhi lamanya waktu penyelsaian audit laporan keuangan. Semakin besar ukuran perusahaan, penyelesaian audit laporan keuangan menjadi semakin cepat, dan sebaliknya semakin kecil ukuran perusahaan maka audit yang dilakukan menjadi semakin lama. Kondisi ini disebabkan oleh adanya sistem pengendalian internal pada perusahaan besar sehingga dapat mengurangi tingkat kesalahan dalam penyusunan laporan keuangan yang memudahkan auditor dalam melakukan audit laporan keuangan.

2.11.2. Hubungan Opini Auditor dan Audit Delay

Perusahaan yang menerima pendapat selain unqualified opinion mengalami Audit Delay yang lebih panjang. Opini wajar tanpa pengecualian menunjukkan bahwa laporan keuangan yang diterbitkan lebih berkualitas dan dapat dipercaya sehingga memudahkan auditor dalam melakukan proses auditing. Sebaliknya, pemberian pendapat selain unqualified opinion tentunya memerlukan pertimbangan yang lebih matang dengan melibatkan negosiasi dengan klien, konsultasi dengan partner audit yang lebih senior atau staf teknis dan perluasan lingkup audit (Yuliusman et.al., 2020). Perusahaan yang menerima opini wajar tanpa pengecualian tentunya akan mendapatkan laporan hasil audit tepat waktu. Opini audit wajar tanpa pengecualian mengemukakan bahwa laporan keuangan yang telah diaudit sesuai dengan ketentuan standar akuntansi keuangan dan tidak ada penyimpangan material yang dapat mempengaruhi pengambilan suatu keputusan.

2.11.3. Hubungan Solvabilitas dan Audit Delay

Solvabilitas merupakan faktor yang mempengaruhi audit delay. Hal ini terlihat dari hasil penelitian Carlaw dan Kaplan (1991) dalam Yuliusman et.al. (2020) menemukan hubungan yang signifikan antara solvabilitas yang diukur menggunakan rasio Total Debt to Total Asset (TDTA) dengan Audit Delay. Proporsi total debt to total assets ratio yang tinggi menunjukkan rendahnya kemampuan perusahaan menjamin hutang yang dimiliki. Kondisi ini membuat auditor akan meningkatkan perhatian bahwa ada kemungkinan laporan keuangan kurang dapat dipercaya. Pada sisi lain, audit terhadap nilai hutang memerlukan waktu yang lebih lama dibandingkan dengan mengaudit modal. Lamanya audit membuat perusahaan akan mengurangi resiko dengan mengundurkan publikasi laporan keuangannya dan mengulur waktu dalam laporan auditnya (Yuliusman, et.al., 2020).

2.11.4. Hubungan Profitabilitas dan Audit Delay Profitabilitas perusahaan dapat dilihat dari nilai laba bersih sesudah pajak yang diterima perusahaan. Perusahaan yang mengalami kerugian dengan tingkat profitabilitas yang rendah, akan membawa reaksi negatif terhadap pasar dan turunnya penilaian atas kinerja perusahaannya. Penelitian Syachruddin dan Nurlis (2018) menemukan bukti bahwa profitabilitas yang berpengaruh negatif dan signifikan terhadap audit delay. Hal ini berarti bahwa profitabilitas perusahaan yang lebih rendah akan membutuhkan penyelesaian audit lebih lama. Ada beberapa alasan yang mendorong terjadinya kemunduran laporan publikasi yaitu pelaporan laba atau rugi sebagai indikator good news atau bad news atas kinerja menejerial perusahaan dalam setahun.

\subsubsection{Hubungan Komite Audit dan Audit Delay}

Komite audit berfungsi membantu eomisaris dalam memastikan efektifitas system pengendalian intern, efektifitas pelaksanaan tugas auditor eksternal dan auditor internal. Setiap perusahaan wajib membentuk komite audit dengan anggota minimal 3 orang. Komite audit mempunyai peran yang sangat penting dan strategis dalam hal memelihara kredibilitas proses penyusunan laporan keuangan seperti halnya menjaga terciptanya sistem pengawasan perusahaan yang memadai serta dilaksanakannya corporate governance (FCGI, 2000).

\subsubsection{Hubungan Reputasi KAP dan Audit Delay}

Interaksi reputasi KAP dengan ukuran perusahaan, opini audit, solvabilitas, profitabilitas dan komite audit akan mempengaruhi audit delay. KAP big four umumnya mempunyai sumber daya yang lebih besar sehingga dapat melakukan audit lebih cepat dan efisien. Hal ini membuktikan pendapat bahwa perusahaan yang diaudit oleh KAP big four cenderung lebih cepat menyelesaikan auditnya bila dibandingkan dengan perusahaan yang diaudit oleh KAP non big four. Penelitian Murti dan Widhiyani (2016) menunjukkan 
bahwa variabel reputasi KAP memoderasi pengaruh ukuran perusahaan dan profitabilitas terhadap audit delay. Sementara itu, dalam penelitian Juwita et.al. (2020), ukuran kantor akuntan publik berhasil memoderasi hubungan antara komite audit dan audit report lag.

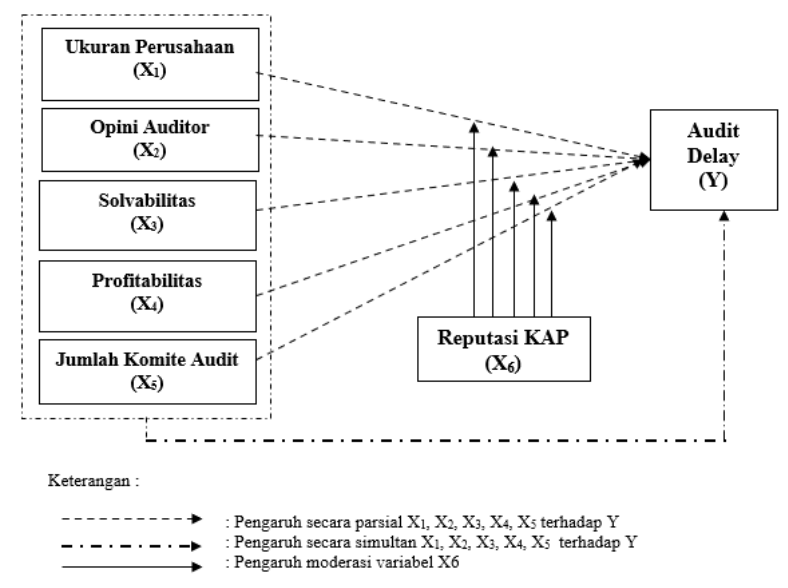

Sumber: data olahan

Gambar 1. Kerangka Pemikiran

\section{METODOLOGI PENELITIAN}

Metode penelitian yang digunakan dalam penelitian ini adalah explanatory research. Singarimbun dan Effendi (2008) menjelaskan explanatory research yaitu penelitian yang digunakan untuk menjelaskan hubungan kausal antara variabel-variabel melalui pengujian hipotesa yang dirumuskan. Pendekatan penelitian menggunakan pendekatan kuantitatif yang merupakan penekanan pada pengujian teori melalui pengukuran variabel penelitian dengan angka dan melakukan analisis data dengan prosedur statistik. Rancangan atau desain penelitian yang digunakan dalam penelitian ini yaitu desain korelasional. Studi korelasional digunakan dalam penelitian ini untuk mempelajari hubungan dua variabel atau lebih, yakni sejauh mana variasi dalam satu variabel berhubungan dengan variasi dalam variabel lain (Sudjana dan Ibrahim, 2007).

Populasi penelitian ini adalah perusahaan LQ-45 yang listing dari tahun 2015 - 2019 di Bursa Efek Indonesia. Teknik penarikan sampel penelitian adalah dengan menggunakan metode purposive sampling yaitu sampel dipilih atas dasar kesesuaian karakteristik sampel dengan kriteria pemilihan sampel yang ditentukan (Ghozali, 2014). Sampel yang dipilih dalam penelitian ini adalah perusahaan LQ-45 yang secara konsisten terdaftar dalam indeks LQ-45 selama periode tahun 2015 - 2019.

Tabel 1. Proses Purposive Sampling Penelitian

\begin{tabular}{|c|l|c|}
\hline No & \multicolumn{1}{|c|}{ Purposive Sampling } & Jumlah \\
\hline 1 & $\begin{array}{l}\text { Perusahaan yang terdaftar dalam indeks LQ-45 Periode Februari 2015 - } \\
\text { Juli 2015 }\end{array}$ & 45 \\
\hline 2 & $\begin{array}{l}\text { Dikurangi perusahaan yang tidak konsisten terdaftar dalam indeks LQ- } \\
45 \text { selama periode 2015 - 2019. }\end{array}$ & $(17)$ \\
\hline \multicolumn{1}{|c|}{ Jumlah } & 28 \\
\hline
\end{tabular}

Sumber : Kriteria pemilihan sampel

Berdasarkan data kualifikasi di atas, maka terdapat 28 perusahaan yang dapat dijadikan sampel dalam penelitian ini selama periode pengamatan 5 tahun, dengan total 140 data pengamatan.

Analisis data dalam penelitian ini dilakukan dengan metode analisis data panel dan uji selisih mutlak. Uji selisih mutlak dilakukan untuk Untuk menguji pengaruh moderasi reputasi KAP terhadap hubungan antara ukuran perusahaan, opini audit, solvabilitas, profitabilitas, dan komite audit dengan audit delay.

Model analisis dalam penelitian ini disajikan dalam persamaan sebagai berikut:

$Y=\alpha+\beta_{1} X_{1}+\beta_{2} X_{2}+\beta_{3} X_{3}+\beta_{4} X_{4}+\beta_{5} X_{5}+\beta_{6} X_{6}+\beta_{7}\left|X_{1} X_{6}\right|+\beta_{8}\left|X_{2} X_{6}\right|+\beta_{9}\left|X_{3} X_{6}\right|+$ $\beta_{10}\left|X_{4} X_{6}\right|+\beta_{11}\left|X_{5} . X_{6}\right|+e$

\begin{tabular}{|c|c|c|}
\hline \multicolumn{2}{|c|}{ Keterangan: } & $\left|X_{2} \cdot X_{6}\right|=$ Interaksi antara opini audit dengan \\
\hline $\mathrm{Y}$ & Audit Delay & reputasi KAP yang diukur berdasarkan \\
\hline A & Konstanta. & nilai interaksi antara $X_{2}$ dan $X_{6}$ \\
\hline$\beta_{1}-\beta_{11}$ & Koefisien Regresi. & $\left|\mathrm{X}_{3} . \mathrm{X}_{6}\right|=$ Interaksi antara solvabilitas dengan reputasi \\
\hline $\mathrm{X}_{1}$ & Ukuran Perusahaan. & KAP yang diukur berdasarkan nilai \\
\hline $\mathrm{X}_{2}$ & $=$ Opini Audit. & interaksi antara $\mathrm{X}_{3}$ dan $\mathrm{X}_{6}$ \\
\hline $\mathrm{X}_{3}$ & Solvabilitas & $\left|\mathrm{X}_{4} \cdot \mathrm{X}_{6}\right|=$ Interaksi antara profitabilitas dengan reputasi \\
\hline $\mathrm{X}_{4}$ & Profitabilitas & KAP yang diukur berdasarkan nilai \\
\hline & $=$ Jumlah Komite Audit & interaksi antara $\mathrm{X}_{4}$ dan $\mathrm{X}_{6}$ \\
\hline & $=$ Reputasi KAP & $\left|X_{5} . X_{6}\right|=$ Interaksi antara jumlah komite audit dengan \\
\hline$\left|X_{1} \cdot X_{6}\right|$ & $\begin{aligned}= & \text { Interaksi antara ukuran perusahaan } \\
& \text { dengan reputasi KAP yang diukur } \\
& \text { berdasarkan nilai interaksi antara } \mathrm{X}_{1} \text { dan }\end{aligned}$ & $\begin{array}{l}\text { reputasi KAP yang diukur berdasarkan } \\
\text { nilai interaksi antara } \mathrm{X}_{5} \text { dan } \mathrm{X}_{6} \text {. } \\
\text { Error }\end{array}$ \\
\hline
\end{tabular}


Faktor-Faktor yang Mempengaruhi Audit Delay dengan Reputasi KAP Sebagai Variabel Pemoderasi (Studi Pada Perusahaan LQ 45 yang Terdaftar di Bursa Efek Indonesia Pada Tahun 2015 - 2019) (Fuad Rahardi, Afrizal, dan Enggar Diah PA)

\subsection{Pemilihan Metode Estimasi Analisis Data Panel}

Analisis data panel dilakukan menggunakan tiga pendekatan untuk mengestimasi, antara lain dengan metode common effect, fixed effect dan random effect. Oleh karena itu perlu melakukan pengujian untuk menentukan mana diantara ketiga pendekatan tersebut yang paling sesuai dengan data yang digunakan.

\subsubsection{Pengujian Antara Metode Common Effect atau Metode Fixed Effect}

Pengujian model terbaik antara menggunakan metode common effect atau dengan menggunakan metode individual effect (yang diawali oleh model fixed effect) menggunakan redundant fixed effect test terlebih dahulu membuat hipotesis:

$$
H_{0}: \alpha 1=\alpha 2=\alpha 3=\ldots=\alpha \mathrm{i}, \text { Common Effect }
$$

$H_{a}: \alpha 1 \neq \alpha 2 \neq \alpha 3 \neq \ldots \neq \ldots$ i, Individual Effect

Pengambilan keputusan apakah $\mathrm{H}_{0}$ atau $\mathrm{H}_{\mathrm{a}}$ yang diterima yaitu dengan membandingkan hasil $\mathrm{F}_{\text {hitung }}$ dengan $\mathrm{F}_{\text {tabel }} . \mathrm{F}_{\text {tabel }}$ dicari pada $\alpha$ tertentu untuk $\mathrm{m}$ numerator df dan (n-k) dominator df. Jika $F_{\text {hitung }}$ lebih besar dari $\mathrm{F}_{\text {tabel }}$ maka $\mathrm{H}_{0}$ ditolak sehingga $\mathrm{H}_{0}$ diterima artinya model yang digunakan adalah individual effect (fixed effect). Sebaliknya jika $\mathrm{F}_{\text {hitung }}$ lebih kecil dari $\mathrm{F}_{\text {tabel }}$ maka $\mathrm{H}_{0}$ diterima sehingga $\mathrm{H}_{\mathrm{a}}$ ditolak yang artinya model yang digunakan adalah common effect.

\subsubsection{Pengujian Antara Metode Fixed Effect atau} Metode Random Effect

Pengambilan keputusan apakah menggunakan fixed effect atau random effect dilakukan dengan menggunakan haustman test. Dilihat dengan menggunakan nilai probability ( $p$-value) sehingga keputusan pemilihan kedua model tersebut akan dapat ditentukan secara statistik. Sebelum melakukan pengujian yang pertama kita membuat hipotesis dulu:

$\mathrm{H}_{0}$ : Ada gangguan antar individu (random effect)

$\mathrm{H}_{\mathrm{a}}$ : Tidak ada gangguan antar individu (fixed effect)

Pengambilan keputusan didasarkan pada membandingkan hasil haussman test ini, dimana jika $p$ value lebih kecil 0,05 , maka $\mathrm{H}_{0}$ ditolak dan $\mathrm{H}_{\mathrm{a}}$ diterima, berarti analisis yang digunakan yaitu metode fixed effect. Sebaliknya jika $p$-value lebih besar dari 0,05 , maka $\mathrm{H}_{0}$ diterima dan $\mathrm{H}_{\mathrm{a}}$ ditolak, berarti analisis yang digunakan yaitu dengan metode random effect.

\subsubsection{Pengujian Antara Metode Common Effect atau Metode Random Effect}

Pengambilan keputusan apakah menggunakan common effect atau random effect dilakukan dengan menggunakan langrange multiplier (LM) test. Dilihat dengan menggunakan nilai probability (p-value) sehingga keputusan pemilihan kedua model tersebut akan dapat ditentukan secara statistik. Sebelum melakukan pengujian yang pertama kita membuat hipotesis dulu:

$\mathrm{H}_{0}$ : Menerima penggunaan metode common effect

$\mathrm{H}_{\mathrm{a}}$ : Menerima penggunaan metode random effect

Pengambilan keputusan didasarkan pada membandingkan hasil LM-Test, dimana jika $p$-value lebih kecil 0,05, maka $\mathrm{H}_{0}$ ditolak dan $\mathrm{H}_{\mathrm{a}}$ diterima, berarti analisis yang digunakan yaitu metode random effect. Sebaliknya jika $p$-value lebih besar dari 0,05 , maka $\mathrm{H}_{0}$ diterima dan $\mathrm{H}_{\mathrm{a}}$ ditolak, berarti analisis yang digunakan yaitu dengan metode common effect.

\subsection{Pengujian Hipotesis}

Metode pengujian terhadap hipotesis yang diajukan dilakukan menggunakan uji $\mathrm{t}$ dan koefisien derteminasi. Pengujian hipotesis tersebut sebagai berikut:

3.2.1 Uji Statistik t

Uji t dipergunakan untuk mengukur secara parsial pengaruh variabel bebas $(\mathrm{X})$ terhadap variabel terikat (Y). Uji ini dilakukan dengan membandingkan signifikansi $\mathrm{t}$ hitung dengan $\mathrm{t}$ tabel dengan ketentuan sebagai berikut:

Jika $\mathrm{t}_{\text {hitung }} \leq \mathrm{t}_{\text {tabel}}$, atau $-\mathrm{t}_{\text {hitung }} \geq-\mathrm{t}_{\text {tabel}}$, maka $\mathrm{H} 0$ diterima.

Jika $\mathrm{t}_{\text {hitung }}>\mathrm{t}$ tabel, atau $-\mathrm{t}_{\text {hitung }}<-\mathrm{t}_{\text {tabel, maka Ha }}$ diterima.

\subsubsection{Koefisien Determinasi $\left(\mathrm{R}^{2}\right)$}

Koefisien determinasi $\left(\mathrm{R}^{2}\right)$ pada intinya mengukur seberapa jauh kemampuan model dalam menerangkan variasi variabel dependen. Dalam penelitian ini digunakan nilai Adjusted $R^{2}$. Nilai Adjusted $R^{2}$ dapat naik atau turun apabila satu variabel independen ditambahkan ke dalam model.

\section{HASIL DAN PEMBAHASAN}

\subsection{Hasil Penelitian}

\subsubsection{Pemilihan Model Analisis Data Panel}

Untuk menentukan hasil analisis data panel terbaik pada penelitian ini, maka terlebih dahulu dilakukan pemilihan model yang sesuai dengan data penelitian dengan langkah-langkah sebagai berikut:

1. Pemilihan Antara Model Common Effect atau Model Fixed Effect

Pemilihan model estimasi common effect dan fixed effect dilakukan dengan menggunakan redundant fixed effect test dengan hasil sebagai berikut:

Tabel 2. Redundant Fixed Effect Test

\begin{tabular}{|l|r|r|r|}
\hline \multicolumn{1}{|c|}{ Effects Test } & \multicolumn{1}{c|}{ Statistic } & \multicolumn{1}{c|}{ d.f. } & \multicolumn{1}{c|}{ Prob. } \\
\hline Cross-section F & 3.084281 & $(27,101)$ & 0.0000 \\
\hline Cross-section Chi-square & 84.183653 & 27 & 0.0000 \\
\hline
\end{tabular}

Sumber: Hasil pengolahan data, 2020 
Berdasarkan tabel 2 di atas didapatkan nilai Probability Cross-section $F=0,0000$ lebih kecil dari taraf signifikansi 0,05 . Hal ini berarti $\mathrm{H}_{0}$ diterima dan Ha ditolak. Dengan demikian pada model data panel terdapat gangguan individu atau dengan kata lain bahwa analisis sebaiknya menggunakan model fixed effect daripada model common effect.

\section{Pemilihan Antara Model Random Effect atau Model Fixed Effect}

Pengambilan keputusan apakah menggunakan model fixed effect atau menggunakan model random effect dilakukan dengan menggunakan haussman test. Pengambilan keputusan dengan membandingkan nilai $p$-value dengan taraf signifikansi $\alpha=0,05$, jika $p$-value lebih kecil dari 0,05 maka analisis yang digunakan sebaiknya model fixed effect. Sebaliknya jika $p$-value lebih besar dari 0,05 maka analisis sebaiknya menggunakan model random effect (Gujarati, 2011). Hasil pengujian haussman test adalah sebagai berikut:

Tabel 3. Hasil Haussman Test

\begin{tabular}{|c|r|r|r|}
\hline \multicolumn{1}{|c|}{ Test Summary } & Chi-Sq. Statistic & Chi-Sq. d.f. & \multicolumn{1}{c|}{ Prob. } \\
\hline Cross-section random & 28.278727 & & 11 \\
\hline
\end{tabular}

Sumber: Hasil pengolahan data, 2020

Berdasarkan tabel 3 di atas dapat dilihat bahwa p-value yaitu 0,0029 lebih kecil dari 0,05. Hal ini berarti $\mathrm{H}_{0}$ ditolak dan $\mathrm{H}_{\mathrm{a}}$ diterima, yang berarti asumsi penerimaan model fixed effect diterima dan menolak asumsi penggunaan model random effect. Dengan demikian, berdasarkan hasil Haussman test menunjukkan bahwa model yang sebaiknya digunakan adalah model fixed effect.

3. Pemilihan Antara Model Common Effect atau Model Random Effect

Pemilihan model antara common effect dan fixed effect menggunakan metode redundant fixed effect test menunjukkan bahwa model yang sebaiknya digunakan adalah model fixed effect. Sementara itu, berdasarkan hasil haussman test menunjukkan bahwa model analisis yang

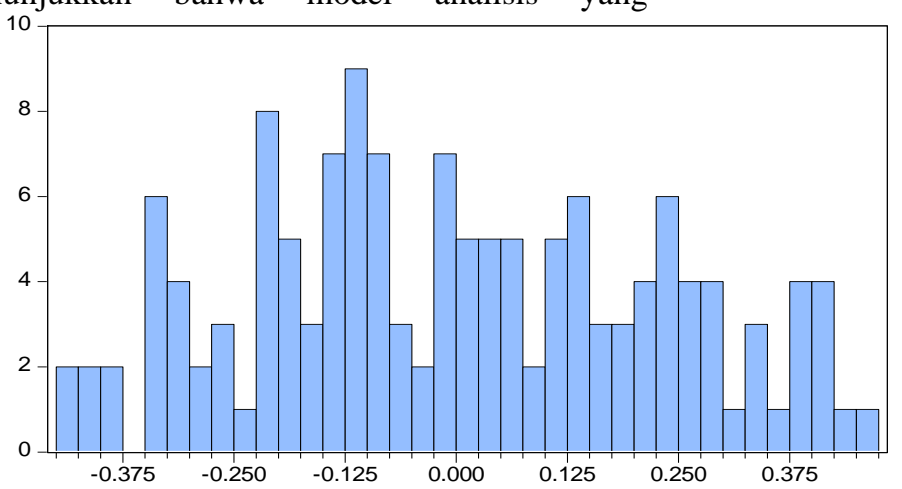

Sumber: Hasil pengolahan data, 2020

\section{Gambar 2. Hasil Uji Normalitas}

Berdasarkan data di atas dapat dilihat bahwa nilai Jarque Bera $=5,111344$, sedangkan nilai $\chi^{2}$ tabel dengan $\mathrm{dk}=\mathrm{k}=11$ yaitu sebesar 19,67514 . Nilai Jarque Bera $(5,111344)<19,67514$, hal ini berarti residual berdistribusi normal. Hal ini berarti bahwa pada model analisis data panel memenuhi asumsi uji normalitas. sebaiknya digunakan juga adalah model fixed effect. Oleh karena itu, tidak lagi diperlukan perbandingan antara common effect dan random effect, karena dari hasil redundant fixed effect test dan haussman test sudah jelas bahwa model yang terbaik digunakan adalah fixed effect.

\subsubsection{Hasil Uji Asumsi Klasik}

Uji asumsi klasik yang dilakukan antara lain yaitu uji normalitas, uji multikolinearitas, uji autokorelasi dan uji heterokedastisitas. Uji asumsi klasik yang dilakukan yaitu sebagai berikut:

\section{Hasil Uji Normalitas}

Hasil uji normalitas pada analisis data panel dengan menggunakan histogram normality test pada model analisis fixed effect dengan Eviews 8.0 adalah sebagai berikut:

\begin{tabular}{lc|} 
Series: Standardized Residuals \\
Sample 2015 2019 \\
Observations & 140 \\
& \\
Mean & $-3.49 \mathrm{e}-17$ \\
Median & -0.011591 \\
Maximum & 0.454502 \\
Minimum & -0.434319 \\
Std. Dev. & 0.227950 \\
Skewness & 0.107686 \\
Kurtosis & 2.089042 \\
& \\
Jarque-Bera & 5.111344 \\
Probability & 0.077640 \\
\hline
\end{tabular}

Series: Standardized Residuals Sample 20152019

Mean $\quad-3.49 \mathrm{e}-17$ $-0.011591$

Std. Dev. $\quad 0.227950$

Skewness $\quad 0.107686$

Jarque-Bera $\quad 5.111344$

Probability $\quad 0.077640$ 
Faktor-Faktor yang Mempengaruhi Audit Delay dengan Reputasi KAP Sebagai Variabel Pemoderasi (Studi Pada Perusahaan LQ 45 yang Terdaftar di Bursa Efek Indonesia Pada Tahun 2015 - 2019) (Fuad Rahardi, Afrizal, dan Enggar Diah PA)

Tabel 4. Matriks Korelasi antar Variabel Independen

\begin{tabular}{|c|c|c|c|c|c|c|c|c|c|c|c|}
\hline & $\mathrm{X} 1$ & $\mathrm{X} 1 \mathrm{X} 6$ & $\mathrm{X} 2$ & $\mathrm{X} 2 \mathrm{X} 6$ & $\mathrm{X} 3$ & $\mathrm{X} 3 \mathrm{X} 6$ & $\mathrm{X} 4$ & $\mathrm{X} 4 \mathrm{X} 6$ & $\mathrm{X} 5$ & $\mathrm{X} 5 \mathrm{X} 6$ & $\mathrm{X} 6$ \\
\hline $\mathrm{X} 1$ & 1.000 & -0.288 & -0.028 & -0.029 & 0.584 & -0.185 & -0.593 & -0.165 & 0.495 & -0.030 & 0.148 \\
\hline $\mathrm{X} 1 \mathrm{X} 6$ & -0.288 & 1.000 & -0.497 & 0.475 & 0.113 & 0.519 & 0.262 & 0.516 & -0.062 & 0.413 & -0.558 \\
\hline $\mathrm{X} 2$ & -0.028 & -0.497 & 1.000 & -0.636 & -0.274 & -0.283 & 0.057 & -0.224 & -0.108 & -0.172 & 0.306 \\
\hline $\mathrm{X} 2 \mathrm{X} 6$ & -0.029 & 0.475 & -0.636 & 1.000 & 0.120 & 0.188 & -0.045 & 0.320 & 0.059 & 0.206 & -0.418 \\
\hline $\mathrm{X} 3$ & 0.584 & 0.113 & -0.274 & 0.120 & 1.000 & -0.164 & -0.211 & 0.377 & 0.479 & 0.174 & -0.102 \\
\hline $\mathrm{X} 3 \mathrm{X} 6$ & -0.185 & 0.519 & -0.283 & 0.188 & -0.164 & 1.000 & -0.227 & 0.161 & -0.105 & 0.555 & -0.709 \\
\hline $\mathrm{X} 4$ & -0.593 & 0.262 & 0.057 & -0.045 & -0.211 & -0.227 & 1.000 & 0.296 & -0.168 & -0.129 & 0.177 \\
\hline $\mathrm{X} 4 \mathrm{X} 6$ & -0.165 & 0.516 & -0.224 & 0.320 & 0.377 & 0.161 & 0.296 & 1.000 & 0.078 & 0.390 & -0.525 \\
\hline $\mathrm{X} 5$ & 0.495 & -0.062 & -0.108 & 0.059 & 0.479 & -0.105 & -0.168 & 0.078 & 1.000 & 0.222 & 0.028 \\
\hline X5X6 & -0.030 & 0.413 & -0.172 & 0.206 & 0.174 & 0.555 & -0.129 & 0.390 & 0.223 & 1.000 & -0.663 \\
\hline X6 & 0.148 & -0.558 & 0.306 & -0.418 & -0.102 & -0.709 & 0.177 & -0.525 & 0.028 & -0.663 & 1.000 \\
\hline
\end{tabular}

Sumber: Hasil pengolahan data, 2020

Berdasarkan tabel di atas dapat dilihat bahwa nilai koefisien korelasi antar variabel independen tidak ada yang lebih besar dari 0,8 , hal ini berarti bahwa tidak terdapat gejala multikolinearitas pada variabel independen.

3. Hasil Uji Autokorelasi
Untuk mengetahui ada tidaknya autokorelasi dapat dilakukan dengan uji Durbin Watson. Kriteria yang digunakan untuk mendeteksi ada tidaknya gejala autokorelasi berdasarkan nilai tabel Durbin Watson DL (batas bawah) dan DU (batas atas) adalah sebagai berikut:

Tabel 5. Hasil Uji Autokorelasi Analisis Data Panel

\begin{tabular}{|c|c|c|}
\hline DW & Kesimpulan & Nilai DW \\
\hline $0<\mathrm{DW} \leq 1,5582$ & Ada autokorelasi positif & \\
\hline $1,5582<\mathrm{DW} \leq 1,8955$ & Tdk ada Kesimpulan & \\
\hline $1,8955<\mathrm{DW} \leq 2,1045$ & Tdk ada autokorelasi & 2,1301 \\
\hline $2,1045<\mathrm{DW} \leq 2,4418$ & Tidak ada kesimpulan & \\
\hline $2,4418<\mathrm{DW} \leq 4$ & Ada autokorelasi negatif & \\
\hline
\end{tabular}

Sumber: Hasil pengolahan data, 2020

Berdasarkan hasil analisis data diketahui bahwa nilai Durbin Watson sebesar 2,1301 terletak pada interval $2,1045<\mathrm{DW} \leq 2,4418$ dengan kriteria tidak ada kesimpulan. Hal ini berarti bahwa pada model analisis yang digunakan tidak dapat dipastikan ada atau tidaknya gangguan autokorelasi dan bisa dilanjutkan ke analisis selanjutnya.

4. Uji Heteroskedastisitas

Masalah heterokedastisitas pada data panel dapat dihilangkan dengan memberikan white robust error, atau pada aplikasi Eviews 9.0 disebut white's standard error. Periode penelitian yang pendek menyebabkan kesulitan dalam mendeteksi apakah heterokedastisitas diakibatkan oleh heterogenitas antar individu atau antar waktu, oleh karena itu untuk data panel dengan periode yang pendek digunakan White's diagonal standard errors and covariance.

4.4.3 Analisis Data Panel dengan Metode Fixed Effect Pemilihan model analisis data panel dalam penelitian ini menunjukkan bahwa model estimasi yang sebaiknya digunakan untuk menguji hipotesis penelitian sebaiknya menggunakan model fixed effect. Hasil analisis data panel dengan model estimasi fixed effect digambarkan dalam tabel berikut ini:

Tabel 6. Koefisien Regresi

\begin{tabular}{|c|r|}
\hline Variabel & Koefisien \\
\hline C & 1,353379 \\
\hline X1 & 0,046723 \\
\hline X2 & 0,011278 \\
\hline X3 & 0,009934 \\
\hline X4 & $-0,005769$ \\
\hline X5 & 0,226755 \\
\hline X6 & 0,481261 \\
\hline X1X6 & $-0,184700$ \\
\hline X2X6 & 0,054183 \\
\hline X3X6 & 0,201471 \\
\hline X4X6 & 0,016418 \\
\hline X5X6 & 0,009837 \\
\hline
\end{tabular}

Sumber: Hasil pengolahan data, 2020 
Berdasarkan tabel 6 di atas, dari koefisien regresi dibentuk persamaan regresi sebagai berikut:

$\mathrm{Y}=1,353379+0,046723 \mathrm{X}_{1}+0,011278 \mathrm{X}_{2}+$ $0,009934 \mathrm{X}_{3}-0,005769 \mathrm{X}_{4}+0,226755 \mathrm{X}_{5}+0,481261$ $\mathrm{X}_{6}-0,184700\left|\mathrm{X}_{1}-\mathrm{X}_{6}\right|+0,054183\left|\mathrm{X}_{2}-\mathrm{X}_{6}\right|+0,201471$ $\left|X_{3}-X_{6}\right|+0,016418\left|X_{4}-X_{6}\right|+0,009837\left|X_{5}-X_{6}\right|$

Berdasarkan tabel di atas dapat dirumuskan halhal sebagai berikut:

1. Nilai konstan (c) $=1,353379$, berarti bahwa pada saat ukuran perusahaan, opini audit, solvabilitas, profitabilitas, komite audit, reputasi KAP, dan semua variabel moderasi sama dengan 0, maka audit delay bernilai positif sebesar 1,353379 satuan.

2. Koefisien regresi variabel ukuran perusahaan bernilai positif sebesar 0,046723, hal ini memperlihatkan bahwa apabila ukuran perusahaan pada perusahaan LQ-45 di BEI tahun 2015 - 2019 mengalami peningkatan sebesar $1 \%$, maka nilai audit delay akan bertambah sebesar 0,046723 satuan pada saat variabel yang lain diasumsikan konstan.

3. Koefisien regresi variabel opini audit bernilai positif sebesar 0,011278, hal ini memperlihatkan bahwa apabila perusahaan dengan opini audit wajar tanpa pengecualian dengan audit delay lebih lama dengan selisih sebesar $0,011278 \%$ pada saat variabel yang lain diasumsikan konstan.

4. Koefisien regresi variabel solvabilitas bernilai positif sebesar 0,009934, hal ini memperlihatkan bahwa apabila nilai solvabilitas perusahaan LQ-45 di BEI tahun 2015 - 2019 meningkat sebesar 1\%, maka akan terjadi peningkatan audit delay sebesar 0,009934\% satuan pada saat variabel yang lain diasumsikan konstan.

5. Koefisien regresi variabel profitabilitas bernilai negatif sebesar 0,005769 , hal ini memperlihatkan bahwa apabila nilai profitabilitas perusahaan LQ45 di BEI tahun 2015 - 2019 meningkat sebesar $1 \%$, maka akan terjadi penurunan audit delay sebesar 0,005769\% satuan pada saat variabel yang lain diasumsikan konstan.

6. Koefisien regresi variabel komite audit bernilai positif sebesar 0,226755, hal ini memperlihatkan bahwa apabila jumlah anggota komite audit bertambah satu orang, maka akan terjadi peningkatan audit delay sebesar 0,226755\% satuan pada saat variabel yang lain diasumsikan konstan.

7. Koefisien regresi variabel reputasi KAP bernilai positif sebesar 0,481261, hal ini memperlihatkan bahwa apabila perusahaan yang menggunakan KAP Big Four memiliki audit delay yang lebih singkat dibanding dengan perusahaan yang menggunakan KAP Non Big Four dengan selisih sebesar 0,481261\% pada saat variabel yang lain diasumsikan konstan.

8. Koefisien regresi variabel interaksi antara reputasi KAP dengan ukuran perusahaan bernilai negatif sebesar 0,184700, hal ini memperlihatkan bahwa apabila interaksi antara reputasi KAP dengan ukuran perusahaan pada perusahaan LQ-45 di BEI tahun 2015 - 2019 mengalami peningkatan sebesar 1\%, maka nilai audit delay akan mengalami peningkatan sebesar $0,184700 \%$ pada saat variabel yang lain diasumsikan konstan.

9. Koefisien regresi variabel interaksi antara reputasi KAP dengan opini audit bernilai positif sebesar 0,054183, hal ini memperlihatkan bahwa apabila interaksi antara reputasi KAP dengan opini audit pada perusahaan LQ-45 di BEI tahun 2015 - 2019 meningkat sebesar 1\%, maka audit delay cenderung mengalami peningkatan sebesar $0,054183 \%$ pada saat variabel yang lain diasumsikan konstan.

10. Koefisien regresi variabel interaksi antara reputasi KAP dengan solvabilitas bernilai positif sebesar 0,201471, hal ini memperlihatkan bahwa apabila interaksi antara reputasi KAP dengan nilai solvabilitas perusahaan LQ-45 di BEI tahun 2015 - 2019 meningkat sebesar 1\%, maka akan terjadi peningkatan audit delay sebesar 0,201471\% pada saat variabel yang lain diasumsikan konstan.

11. Koefisien regresi variabel interaksi antara reputasi KAP dengan profitabilitas bernilai positif sebesar 0,016418, hal ini memperlihatkan bahwa apabila interaksi antara reputasi KAP dengan nilai profitabilitas perusahaan LQ-45 di BEI tahun 2015 - 2019 meningkat sebesar 1\%, maka akan terjadi peningkatan audit delay sebesar $0,016418 \%$ pada saat variabel yang lain diasumsikan konstan.

12. Koefisien regresi variabel interaksi antara reputasi KAP dengan komite audit bernilai positif sebesar 0,009837, hal ini memperlihatkan bahwa apabila interaksi antara reputasi KAP dengan nilai komite audit perusahaan LQ-45 di BEI tahun 2015 - 2019 meningkat sebesar 1\%, maka akan terjadi peningkatan audit delay sebesar 0,009837\% pada saat variabel yang lain diasumsikan konstan.

\subsection{Hasil Pengujian Hipotesis}

Pengujian hipotesis dilakukan dengan menggunakan uji t. Hasil pengujian hipotesis yaitu sebagai berikut:

Tabel 7. Hasil Pengujian Hipotesis

\begin{tabular}{|c|r|r|}
\hline Variable & t-Statistic & \multicolumn{2}{|c|}{ Prob. } \\
\hline $\mathrm{C}$ & 1.467256 & 0.1454 \\
\hline $\mathrm{X} 1$ & 1.190958 & 0.2365 \\
\hline
\end{tabular}


Faktor-Faktor yang Mempengaruhi Audit Delay dengan Reputasi KAP Sebagai Variabel Pemoderasi (Studi Pada Perusahaan LQ 45 yang Terdaftar di Bursa Efek Indonesia Pada Tahun 2015 - 2019) (Fuad Rahardi, Afrizal, dan Enggar Diah PA)

\begin{tabular}{|c|r|r|}
\hline X2 & 0.187538 & 0.8516 \\
\hline X3 & 2.773769 & 0.0066 \\
\hline X4 & -2.940834 & 0.0041 \\
\hline X5 & 3.798337 & 0.0002 \\
\hline X6 & 1.951332 & 0.0538 \\
\hline X1X6 & -3.604529 & 0.0005 \\
\hline X2X6 & 1.304686 & 0.1950 \\
\hline X3X6 & 2.670021 & 0.0088 \\
\hline X4X6 & 0.716688 & 0.4752 \\
\hline X5X6 & 0.135187 & 0.8927 \\
\hline
\end{tabular}

Sumber: Hasil pengolahan data, 2020

Berdasarkan tabel di atas, dapat dijelaskan hal-hal sebagai berikut:

1. Pengujian pengaruh ukuran perusahaan terhadap audit delay

Pada variabel ukuran perusahaan, $t_{\text {hitung }}$ bernilai positif sebesar 1.190958, sedangkan $t_{\text {tabel }}$ pada taraf signifikansi 0,05 dengan $\mathrm{df}=\mathrm{N}-\mathrm{k}=140-$ $11=129$ sebesar 1,979 , $t_{\text {hitung }}<t_{\text {tabel }}$, yang berarti bahwa $\mathrm{H}_{0}$ diterima dan dan $\mathrm{H}_{\mathrm{a}}$ ditolak, dengan demikian ukuran perusahaan berpengaruh negatif namun tidak signifikan terhadap audit delay pada perusahaan LQ-45 di BEI tahun 2015 - 2019.

2. Pengujian pengaruh opini audit terhadap audit delay

Pada variabel opini audit, $t_{\text {hitung }}$ bernilai positif sebesar 0.187538, sedangkan tabel pada taraf signifikansi 0,05 dengan $\mathrm{df}=\mathrm{N}-\mathrm{k}=140-11=$ 129 sebesar 1,979 , thitung $<t_{\text {tabel }}$, yang berarti bahwa $\mathrm{H}_{0}$ diterima dan dan $\mathrm{H}_{\mathrm{a}}$ ditolak, dengan demikian opini audit berpengaruh positif namun tidak signifikan terhadap audit delay pada perusahaan LQ-45 di BEI tahun 2015 - 2019.

3. Pengujian pengaruh solvabilitas terhadap audit delay

Pada variabel solvabilitas, $t_{\text {hitung }}$ bernilai positif sebesar 2.773769, sedangkan $t_{\text {tabel }}$ pada taraf signifikansi 0,05 dengan $\mathrm{df}=\mathrm{N}-\mathrm{k}=140-11=$ 129 sebesar 1,979 , thitung $>t_{\text {tabel }}$, yang berarti bahwa $\mathrm{H}_{0}$ ditolak dan dan $\mathrm{H}_{\mathrm{a}}$ diterima, dengan demikian solvabilitas berpengaruh positif dan signifikan terhadap audit delay pada perusahaan LQ-45 di BEI tahun 2015 - 2019.

4. Pengujian pengaruh profitabilitas terhadap audit delay

Pada variabel profitabilitas, $t_{\text {hitung }}$ bernilai negatif sebesar 2.940834, sedangkan tabel pada taraf signifikansi 0,05 dengan $\mathrm{df}=\mathrm{N}-\mathrm{k}=140-11=$ 129 sebesar 1,979 , thitung $>t_{\text {tabel }}$, yang berarti bahwa $\mathrm{H}_{0}$ diterima dan dan $\mathrm{H}_{\mathrm{a}}$ ditolak, dengan demikian profitabilitas berpengaruh negatif dan signifikan terhadap audit delay pada perusahaan LQ-45 di BEI tahun 2015 - 2019.

5. Pengujian pengaruh komite audit terhadap audit delay

Pada variabel komite audit, $t_{\text {hitung }}$ bernilai positif sebesar 3.798337, sedangkan $t_{\text {tabel }}$ pada taraf signifikansi 0,05 dengan $\mathrm{df}=\mathrm{N}-\mathrm{k}=140-11=$
129 sebesar $1,979, t_{\text {hitung }}>t_{\text {tabel }}$, yang berarti bahwa $\mathrm{H}_{0}$ ditolak dan dan $\mathrm{H}_{\mathrm{a}}$ diterima, dengan demikian komite audit berpengaruh positif dan signifikan terhadap audit delay pada perusahaan LQ-45 di BEI tahun 2015 - 2019.

6. Pengujian pengaruh reputasi KAP dalam memoderasi hubungan antara ukuran perusahaan dengan audit delay

Pada variabel interaksi antara reputasi KAP dan ukuran perusahaan, $t_{\text {hitung }}$ bernilai negatif sebesar 3.604529, sedangkan $t_{\text {tabel }}$ pada taraf signifikansi 0,05 dengan $\mathrm{df}=\mathrm{N}-\mathrm{k}=140-11=129$ sebesar 1,979 , $\mathrm{t}_{\text {hitung }}<\mathrm{t}_{\text {tabel}}$, yang berarti bahwa $\mathrm{H}_{0}$ ditolak dan dan $\mathrm{H}_{\mathrm{a}}$ diterima, dengan demikian reputasi KAP secara signifikan memperlemah hubungan antara ukuran perusahaan dengan audit delay pada perusahaan LQ-45 di BEI tahun 2015 - 2019.

7. Pengujian pengaruh reputasi KAP dalam memoderasi hubungan antara opini audit dengan audit delay

Pada variabel interaksi antara reputasi KAP dan opini audit, $t_{\text {hitung }}$ bernilai positif sebesar 1,304686, sedangkan $t_{\text {tabel }}$ pada taraf signifikansi 0,05 dengan $\mathrm{df}=\mathrm{N}-\mathrm{k}=140-11=129$ sebesar 1,979 , $\mathrm{t}_{\text {hitung }}<$ $\mathrm{t}_{\text {tabel}}$, yang berarti bahwa $\mathrm{H}_{0}$ diterima dan dan $\mathrm{H}_{\mathrm{a}}$ ditolak, dengan demikian reputasi KAP tidak mampu memoderasi hubungan antara opini audit dengan audit delay pada perusahaan LQ-45 di BEI tahun 2015 - 2019.

8. Pengujian pengaruh reputasi KAP dalam memoderasi hubungan antara solvabilitas dengan audit delay

Pada variabel interaksi antara reputasi KAP dan solvabilitas, thitung bernilai positif sebesar 2,670021 , sedangkan $t_{\text {tabel }}$ pada taraf signifikansi 0,05 dengan $\mathrm{df}=\mathrm{N}-\mathrm{k}=140-11=129$ sebesar $1,979, \mathrm{t}_{\text {hitung }}>\mathrm{t}_{\text {tabel}}$, yang berarti bahwa $\mathrm{H}_{0}$ ditolak dan dan $\mathrm{H}_{\mathrm{a}}$ diterima, dengan demikian reputasi KAP secara signifikan mampu memperkuat hubungan antara solvabilitas dengan audit delay pada perusahaan LQ-45 di BEI tahun 2015 - 2019.

9. Pengujian pengaruh reputasi KAP dalam memoderasi hubungan antara profitabilitas dengan audit delay

Pada variabel interaksi antara reputasi KAP dan profitabilitas, $t_{\text {hitung }}$ bernilai positif sebesar 0.716688 , sedangkan $t_{\text {tabel }}$ pada taraf signifikansi 0,05 dengan $\mathrm{df}=\mathrm{N}-\mathrm{k}=140-11=129$ sebesar 
1,979 , $\mathrm{t}_{\text {hitung }}<\mathrm{t}_{\text {tabel}}$, yang berarti bahwa $\mathrm{H}_{0}$ diterima dan dan $\mathrm{H}_{\mathrm{a}}$ ditolak, dengan demikian reputasi KAP tidak mampu memoderasi hubungan antara profitabilitas dengan audit delay pada perusahaan LQ-45 di BEI tahun 2015 - 2019.

10. Pengujian pengaruh reputasi KAP dalam memoderasi hubungan antara komite audit dengan audit delay

Pada variabel interaksi antara reputasi KAP dan komite audit, $t_{\text {hitung }}$ bernilai positif sebesar 0.135187 , sedangkan $t_{\text {tabel }}$ pada taraf signifikansi 0,05 dengan $\mathrm{df}=\mathrm{N}-\mathrm{k}=140-11=129$ sebesar 1,979 , $\mathrm{t}_{\text {hitung }}<\mathrm{t}_{\text {tabel}}$, yang berarti bahwa $\mathrm{H}_{0}$ diterima dan dan $\mathrm{H}_{\mathrm{a}}$ ditolak, dengan demikian reputasi KAP tidak mampu memoderasi hubungan antara komite audit dengan audit delay pada perusahaan LQ-45 di BEI tahun 2015 - 2019.

Besarnya pengaruh ukuran perusahaan, opini audit, solvabilitas, profitabilitas, komite audit, reputasi KAP, dan semua variabel moderasi terhadap audit delay dapat dilihat pada nilai koefisien determinasi (adjusted $R^{2}$ ) dalam tabel 8 berikut ini.

Tabel 8. Koefisien Determinasi

\begin{tabular}{|l|r|}
\hline \multicolumn{1}{|c|}{ Keterangan } & Nilai \\
\hline R-squared & 0.947652 \\
\hline Adjusted R-squared & 0.927957 \\
\hline
\end{tabular}

Sumber: Hasil pengolahan data, 2020

Dari tabel 8 dapat dilihat bahwa besarnya koefisien determinasi (Adjusted $R^{2}$ ) yaitu sebesar 0,927957 . Besarnya pengaruh yaitu $0,927957 \times 100 \%=$ $92,7957 \%$, dan sisanya sebesar 7,2043\% dipengaruhi oleh faktor lain yang tidak termasuk dalam variabel penelitian.

\section{SIMPULAN DAN SARAN}

\subsection{Simpulan}

Berdasarkan hasil penelitian dapat disimpulkan hal-hal sebagai berikut:

1. Ukuran Perusahaan berpengaruh positif namun tidak signifikan terhadap audit delay pada perusahaan LQ-45 di Bursa Efek Indonesia Tahun 2015 - 2019. Hal ini berarti bahwa ukuran perusahaan tidak memberikan dampak yang signifikan terhadap audit delay

2. Opini audit berpengaruh positif namun tidak signifikan terhadap audit delay pada perusahaan LQ-45 di Bursa Efek Indonesia Tahun 2015 2019. Hal ini berarti bahwa opini audit tidak memberikan dampak yang signifikan terhadap audit delay.

3. Solvabilitas berpengaruh positif dan signifikan terhadap audit delay pada perusahaan LQ-45 di Bursa Efek Indonesia Tahun 2015 - 2019. Hal ini berarti bahwa semakin tinggi solvabilitas akan semakin meningkatkan waktu audit delay.

4. Profitabilitas berpengaruh negatif dan signifikan terhadap audit delay pada perusahaan LQ-45 di
Bursa Efek Indonesia Tahun 2015 - 2019. Hal ini berarti bahwa semakin tinggi profitabilitas akan semakin menurunkan waktu audit delay.

5. Komite audit berpengaruh positif dan signifikan terhadap audit delay pada perusahaan LQ-45 di Bursa Efek Indonesia Tahun 2015 - 2019. Hal ini berarti bahwa semakin besar jumlah anggota komite audit akan semakin meningkatkan waktu audit delay.

6. Reputasi KAP mampu memoderasi hubungan antara ukuran perusahaan dengan audit delay pada perusahaan LQ-45 di BEI tahun 2015 - 2019. Hal ini berarti bahwa ukuran perusahaan yang disertai dengan reputasi KAP yang termasuk KAP Big Four mampu memberikan dampak yang signifikan terhadap audit delay sehingga audit delay menjadi lebih cepat.

7. Reputasi KAP tidak mampu memoderasi hubungan antara opini audit dengan audit delay pada perusahaan LQ-45 di BEI tahun 2015 - 2019. Hal ini berarti bahwa opini audit yang disertai dengan reputasi KAP tidak mampu mempengaruhi audit delay.

8. Reputasi KAP mampu memoderasi hubungan antara solvabilitas dengan audit delay pada perusahaan LQ-45 di BEI tahun 2015 - 2019. Hal ini berarti bahwa solvabilitas yang tinggi disertai dengan reputasi KAP yang tergolong Big Four akan meningkatkan audit delay menjadi lebih lama.

9. Reputasi KAP tidak mampu memoderasi hubungan antara profitabilitas dengan audit delay pada perusahaan LQ-45 di BEI tahun 2015 - 2019. Hal ini berarti bahwa profitabilitas yang tinggi yang disertai dengan reputasi KAP tidak mampu mempengaruhi audit delay.

10. Reputasi KAP tidak mampu memoderasi hubungan antara komite audit dengan audit delay pada perusahaan LQ-45 di BEI tahun 2015 - 2019. Hal ini berarti bahwa penambahan anggota komite audit yang disertai dengan reputasi KAP tidak mampu mempengaruhi audit delay.

\subsection{Saran}

Berdasarkan kesimpulan hasil penelitian ini sebagaimana diuraikan di atas, maka peneliti menyumbangkan saran sebagai berikut:

1. Perusahaan LQ-45 di BEI tahun 2015 - 2019 supaya memperhatikan faktor solvabilitas supaya tidak terlalu tinggi yang terbukti bahwa solvabilitas yang tinggi membuat audit delay menjadi lebih lama.

2. Perusahaan LQ-45 di BEI tahun 2015 - 2019 supaya meningkatkan profitabilitas perusahaan yang terbukti mampu menurunkan waktu audit delay laporan keuangan perusahaan.

3. Perusahaan LQ-45 di BEI tahun 2015 - 2019 dengan total aset yang besar sebaiknya menggunakan KAP besar yang tergolong KAP Big Four yang terbukti dari interaksi ukuran perusahaan dengan reputasi KAP mampu 
Faktor-Faktor yang Mempengaruhi Audit Delay dengan Reputasi KAP Sebagai Variabel Pemoderasi (Studi Pada Perusahaan LQ 45 yang Terdaftar di Bursa Efek Indonesia Pada Tahun 2015 - 2019) (Fuad Rahardi, Afrizal, dan Enggar Diah PA)

menurunkan waktu audit delay laporan keuangan perusahaan.

4. Bagi peneliti selanjutnya supaya melakukan penelitian dengan subjek penelitian yang lebih besar dan lebih beragam misalnya dengan menggunakan perusahaan manufaktur atau seluruh perusahaan yang ada di Bursa Efek Indonesia.

5. Bagi peneliti selanjutnya supaya menggunakan periode penelitian yang lebih panjang dan menambahkan variabel-variabel lain yang mempengaruhi audit delay seperti tata kelola perusahaan, pengungkapan informasi dalam laporan keuangan, struktur modal perusahaan, reaksi investor, biaya modal dan lain sebagainya.

\section{DAFTAR REFRENSI}

Ahmed, A. A. A., \& Hossain, S. (2019). Audit Report Lag: A Study of the Bangladeshi Listed Companies. SSRN Electronic Journal, 4(2). https://doi.org/10.2139/ssrn.3406733

Arens, A. A., Elder, R. J., Beasley, M. S., \& Hogan, C. E. (2011). Auditing dan Jasa Assurance. Pendekatan Terintegrasi. Jakarta: Erlangga.

Ari Murti, N. M. D. A., \& Widhiyani, S. (2016). EJurnal Akuntansi Universitas Udayana PADA AUDIT DELAY DENGAN REPUTASI KAP SEBAGAI VARIABEL PEMODERASI Fakultas Ekonomi dan Bisnis Universitas Udayana, Bali, Indonesia Fakultas Ekonomi dan Bisnis Universitas Udayana , Bali , Indonesia ABSTRAK Perkemban, 16, 275-305.

Astika, I. B. P. (2010). Teori Akuntansi: Konsep Konsep Dasar Akuntansi Keuangan. Denpasar: Fakultas Ekonomi Universitas Udayana.

Fanny, D. R., Septiyanti, R., \& Syaippudin, U. (2019). Analysis of Factors Affecting the Audit Delay in Manufacturing Companies Listed in Indonesia Stock Exchange in 2013-2015. International Journal for Innovation Education and Research, $7(12)$, 289-297. https://doi.org/10.31686/ijier.vol7.iss12.2047

FCGI. (2000). Peranan Dewan Komisaris dan Komite Audit dalam Pelaksanaan Corporate Governance (Tata Kelola Perusahaan).

Ghozali, I. (2014). Aplikasi Analisis Multivariate dengan Program SPSS. Semarang: Badan Penerbit Universitas Dipenogoro.

Giri, E. F. (2010). Pengaruh Tenur Kantor Akuntan Publik ( Kap ) Dan Reputasi Kap Terhadap Kualitas Audit: Kasus Rotasi Wajib Auditor Di Indonesia. Simposium Nasional Akuntansi XIII Purwokerto.

Gujarati, D. (2011). Ekonometrika Dasar. Jakarta: Erlangga.
Handayani, A. P., \& Wirakusuma, M. G. (2013). Pengaruh Profitabilitas, Solvabilitas, Reputasi Kantor Akuntan Publik Pada Ketidaktepatwaktuan Publikasi Laporan Keuangan Perusahaan Di Bei. E-Jurnal Akuntansi Universitas Udayana, 4(3), 472-488.

Harahap, S. S. (2011). Teori Akuntansi (Edisi Revi). Jakarta: Rajawali Press.

Ilaboya, O. J., \& Christian, I. (2010). Corporate Governance and Audit Report Lag in Nigeria. Asian Academy of Management Journal of Accounting and Finance, 6(2), 57-84.

Juwita, R., Sutrisno, T., \& Hariadi, B. (2020). Influence of audit committee and internal audit on audit report lag: Size of public accounting firm as a moderating variable. International Journal of Research in Business and Social Science, 9(1), 137-142.

https://doi.org/http://dx.doi.org/10.20525/ijrbs.v9i 1.593

Kartika, A. (2011). Faktor-faktor Yang Mempengaruhi Audit Delay Pada Perusahaan manufaktur Yang Terdaftar Di BEI. Jurnal Dinamika Keuangan Dan Perbankan, 3(2), 152-171.

Kasmir. (2015). Analisis Laporan Keuangan. Jakarta: Rajawali Persada.

Laksono, F. D., \& Mu'id, D. (2014). Analisis Faktorfaktor yang Mempengaruhi Audit Delay dan Ketepatan Waktu Publikasi Laporan Keuangan (Studi Empiris Pada Perusahaan Manufaktur Sektor Consumer Good yang Terdaftar Di BEI Tahun 2010-2012). Diponegoro J. Account, 3(4), 2337-3814.

Modugu, P. K. (2012). Determinants of Audit Delay in Nigerian Companies: Empirical Evidence, 3(6), 46-55.

Mohamad-Nor, M. N., Shafie, R., \& Wan-Hussin, W. N. (2010). Corporate governance and audit report lag in Malaysia. Asian Academy of Management Journal of Accounting and Finance, 6(2), 57-84.

Putra, R., T., S., \& Mardiati, E. (2017). Determinant of audit delay: evidance from public companies in Indonesia. International Journal of Business and Management Invention, 6(6), 12-21. Retrieved from https://www.researchgate.net/publication/3246743 42_Determinant_of_Audit_Delay_Evidance_from _Public_Companies_in_Indonesia

Singarimbun, M., \& Effendi, S. (2006). Metode Penelitian Survei. Jakarta: LP3ES.

Sitanggang, A. Ko. H., \& Ariyanto, D. (2015). Determinan Audit Delay dan Pengaruhnya pada Harga Saham. E-Jurnal Akuntansi Universitas Udayana, 2, 441-455.

Sudjana, N., \& Ibrahim. (2007). PenelItian dan 
Penilaian Pendidikan. Bandung: Sinar Baru Algensindo.

Suharni, S., Sari, S. R. K., \& Wulandari, S. R. (2013). Pengaruh Karakteristik Audit Internal terhadap Ketepatan Waktu Pelaporan Keuangan. Ekomaks, $2,90-102$.

Sutabri. (2012). Analisis Sistem Informasi. Yogyakarta: Andi.

Suwarjono. (2011). Teori Akuntansi: Perekayasaan Pelaporan Keuangan (Edisi Keti). Jakarta: Salemba Empat.

Syachrudin, D., \& Nurlis. (2018). Influence of company size, audit opinion, profitability, solvency, and size of public accountant offices to delay audit onproperty sector manufacturing companies listed in Indonesia stock exchange. International Journal of Scientific and Technology Research, 7(10), 106-111.

Yuliusman, Putra, W. E., Gowon, M., \& Isnaeni, N. (2020). Determinant Factors Audit Delay: Evidence from Indonesia. International Journal of Recent Technology and Engineering, 8(6), 10881095. https://doi.org/10.35940/ijrte.f7560.038620 